\title{
Nonlinear Relationship between Economic Growth and Tax Revenue in Turkey: Hidden Cointegration Approach
}

\section{Türkiye'de Ekonomik Büyüme ile Vergi Geliri Arasındaki Doğrusal Olmayan İlişki: Gizli Eşbütünleşme Yaklaşımı}

\author{
Gülgün ÇIĞDEM ${ }^{1} \odot$, Merve ALTAYLAR ${ }^{2} \odot$
}

\begin{abstract}
The tax revenues, which constitute the most important income item of the state, provide the necessary financing for sustainable economic growth in evolved countries, development efforts in developing economies, and form the basis of social welfare. Therefore, the relationship between economic growth and tax revenues is significant and numerous empirical studies have been carried out on this subject. However, there is no study testing the hidden cointegration. This paper aims to test the presence of hidden cointegration between economic growth and tax revenues and intends to develop further typologies. To test the relationship, data on the ratio of annual tax revenues/ GDP between 1985-2018 in Turkey was used, and Hidden Cointegration Approach developed by Granger and Yoon (2002) and crouching error correction model were applied. The analysis results demonstrated that the tax revenues decreased across variables and that there was a cointegration relationship in periods when the GDP increased. This manuscript is a contribution to the literature since a different technique was performed to examine the relationship between growth and tax revenues, and the results obtained will be crucial for decision-makers.
\end{abstract}

Keywords: GDP, Taxes, Hidden cointegration JEL Classification: O40, H20, E62

\author{
${ }^{1}$ Assoc. Prof., İstanbul Gelişim University, \\ İstanbul, Turkey \\ ${ }^{2}$ Dokuz Eylül University, İzmir, Turkey
}

ORCID: G.Ç. 0000-0001-5353-8638; M.A. 0000-0001-5413-5048

\author{
Corresponding author/Sorumlu yazar: \\ Gülgün Çı̌̆DEM, \\ İstanbul Gelişim University, İstanbul, Turkey \\ E-mail/E-posta: gulguncigdem@gmail.com \\ Submitted/Başvuru: 03.04.2021 \\ Revision Requested/Revizyon Talebi: \\ 07.05.2021 \\ Last Revision Received/Son Revizyon: \\ 07.05.2021 \\ Accepted/Kabul: 07.05.2021 \\ Citation/Atıf: Cigdem, G., \& Altaylar, M. (2021). \\ Nonlinear relationship between economic \\ growth and tax revenue in Turkey: Hidden \\ cointegration approach. Iistanbul iktisat Dergisi \\ - Istanbul Journal of Economics, 71(1), 21-38. \\ https://doi.org/10.26650/ISTJECON2021-908769
}




\section{Introduction}

Economic growth is a complex concept that began to be discussed when Adam Smith questioned its causes in its book named "An Inquiry into the Nature and Causes of the Wealth of Nations" published in 1776, and it has been experienced in various ways since the industrial revolution in 18th century (Yeldan, 2010).

According to Myles (2000), economic growth that remains up-to-date forms the basis of increased welfare. Growth is crucial for increasing individual welfare, and therefore, policies to be selected should be those that ensure growth. One of the necessary and significant factors for economic growth is the availability of an effective tax system. Although taxes (especially income tax) are thought to have a temporary effect in Neoclassical Growth models, tax rates are thought to affect the long-term growth rate or stable state growth rate in Endogenous Growth Models. Tax revenues, which constitute the most significant resource of income for the state, is a considerable tool reducing the gap between the rich and the poor in the society (Chigbu and Njoku, 2015). A well-designed tax system is a crucial element that may increase social welfare (Mankiw, Weinzierl, and Yagan, 2009). Taxation is a key factor in promoting sustainable growth and poverty reduction (Takumah, 2014).

The relationship between growth and tax revenues has been a subject of debate among economists since Smith (1776) for 244 years. In the contraction periods of economies, a decrease is seen in taxes, which constitutes the source of financing of governments, whereas tax revenues increase during economic expansion periods. In this context, the tax revenues of Developed Countries which show steady growth, are higher than the tax revenues of the Developing Countries with unstable growth rates (Goode, 1980). Many empirical studies show that GDP is a substantial variable in determining tax revenues (Piana, 2003). According to Tanzi (1987), the correlation between per capita income and overall tax revenue is positive, especially for developing countries; increased growth raises tax revenue by growing the tax base. 
There is a strong relationship between growth and tax revenues, which is the focal point of many studies. Since the global economic crisis of 2008, many questions have been raised about measures to be taken by governments to promote economic activities (Mutaşcu and Dănuleţiu, 2011). In this context, determining the relationship between growth and tax will allow for establishing an effective tax policy that affects economic growth. In the present manuscript, as a sequel to the study conducted by Çiğdem, Altaylar, Kose, and Yllmaz (2020) in which the relationship between indirect taxes and GDP was analyzed using original data of the variables and in which it was concluded that there was a cointegration relationship among variables exercising the cointegration approach improved by Engle-Granger (1987), the hidden cointegration (HC) relationship between GDP and tax revenues will be studied.

\section{Review of the Literature}

In addition to Smith (1776), Malthus (1798), Ricardo (1817), Ramsey (1928), Young (1928), Schumpeter (1934), Knight (1944), which constitute many elements of modern growth theories, Solow (1956) and Swan (1956) made the most recent and most important contribution (Parasız, 2008). Different approaches seem to be put forward in the discussions on the relationship between growth and tax. For example; the study of Solow (1956) and Swan (1956) indicates that consistent growth is not influenced by tax policies. Lucas (1988) states that a higher rate of income taxes would cause a temporary decrease in growth rate. Romer (1990), carried out studies suggesting that tax policies may have long-term or permanent effects on growth. Easterly and Rebelo (1993) discovered that the standard deviation in the domestic tax revenue-to-consumption-to-investment ratio had a susbstantial and negative effect on economic growth.

Studies of Tanzi and Lee (1996) found that there is no strong evidence associating with the growth with a proper tax policy (Yeldan, 2010). Numerous empirical studies are examining the relationship between growth and tax. Table 1 shows some of those studies. 
Table 1: Literature

\begin{tabular}{|c|c|c|}
\hline Researcher & Method & Result \\
\hline Harberger (1964) & $\begin{array}{l}\text { Equilibrium (Optimal) } \\
\text { Analysis }\end{array}$ & $\begin{array}{l}\text { It established that the growth is not enhanced } \\
\text { by low taxes. }\end{array}$ \\
\hline Marsden (1983) & $\begin{array}{l}\text { Cross-Section Data } \\
\text { Analysis, Linear } \\
\text { Regression }\end{array}$ & $\begin{array}{l}\text { A statistically significant (-) relationship was } \\
\text { found between tax and GDP growth. The } \\
\text { increase in the total tax/GDP ratio decreases } \\
\text { the growth rate. }\end{array}$ \\
\hline Romer (1986) & $\begin{array}{l}\text { Descriptive Statistics and } \\
\text { Equilibrium Analysis }\end{array}$ & $\begin{array}{l}\text { External increase of taxes reduces growth. } \\
\text { High income tax reduces the rate of } \\
\text { sustainable growth. }\end{array}$ \\
\hline $\begin{array}{l}\text { Koester \& Kormendi } \\
\text { (1989) }\end{array}$ & $\begin{array}{l}\text { A Systematic Cross- } \\
\text { Country Analysis. }\end{array}$ & $\begin{array}{l}\text { A }(-) \text { relationship was found between marginal } \\
\text { tax rates and growth. }\end{array}$ \\
\hline $\begin{array}{l}\text { King \& Rebelo } \\
\text { (1990) }\end{array}$ & $\begin{array}{l}\text { Equilibrium Analysis } \\
\text { Descriptive Statistics } \\
\text { (Mathematical } \\
\text { Economics) }\end{array}$ & $\begin{array}{l}\text { An increase in tax rates negatively affects } \\
\text { growth. }\end{array}$ \\
\hline $\begin{array}{l}\text { Easterly \& Rebelo } \\
\text { (1992) }\end{array}$ & $\begin{array}{l}\text { Equilibrium Analysis } \\
\text { Descriptive Statistics } \\
\text { (Mathematical } \\
\text { Economics) }\end{array}$ & $\begin{array}{l}\text { A (-) relationship was found between marginal } \\
\text { tax rates and growth. }\end{array}$ \\
\hline $\begin{array}{l}\text { Easterly \& Rebelo } \\
\text { (1993) }\end{array}$ & $\begin{array}{l}\text { Cross-Section } \\
\text { Regressions }\end{array}$ & $\begin{array}{l}\text { Little evidence were found on a strong } \\
\text { correlation between marginal tax rates and } \\
\text { growth. }\end{array}$ \\
\hline $\begin{array}{l}\text { Ferretti \& Roubini } \\
\text { (1995) }\end{array}$ & Equilibrium Analysis & $\begin{array}{l}\text { They found that taxation would reduce } \\
\text { growth. }\end{array}$ \\
\hline $\begin{array}{l}\text { Engen \& Skinner } \\
\text { (1992) }\end{array}$ & $\begin{array}{l}\text { Cross-Section Data } \\
\text { Analysis, Linear } \\
\text { Regression (OLS } \\
\text { Estimator) } \\
\end{array}$ & An increase in taxation reduces growth rates. \\
\hline $\begin{array}{l}\text { Mendoza, Milesi- } \\
\text { Ferretti } \\
\text { \& Asea (1997) }\end{array}$ & $\begin{array}{l}\text { Cross-Country } \\
\text { Regressions and } \\
\text { Numerical Simulations } \\
\end{array}$ & $\begin{array}{l}\text { Taxes have no impact on economic growth } \\
\text { in the long run. }\end{array}$ \\
\hline Widmalm (2001) & $\begin{array}{l}\text { Pooled Data Analysis } \\
\text { Linear Regression (OLS- } \\
\text { 2SLS Estimators) }\end{array}$ & $\begin{array}{l}\text { The increase in the income tax rate affects the } \\
\text { growth negatively. Furthermore, it was found } \\
\text { that the excise taxes have a weak growth- } \\
\text { enhancing on DC. Tax } \rightarrow \text { GDP }\end{array}$ \\
\hline $\begin{array}{l}\text { Koch, Schoeman \& } \\
\text { Van Tonder (2005) }\end{array}$ & $\begin{array}{l}\text { Time Series Analysis, } \\
\text { Linear Regression (Two- } \\
\text { Stage Modelling) }\end{array}$ & $\begin{array}{l}\text { A decrease in tax burden positively affects the } \\
\text { growth. } \\
\text { Decreased indirect taxation has a strong } \\
\text { association with increased economic growth. }\end{array}$ \\
\hline $\begin{array}{l}\text { Durkaya \& Ceylan } \\
\text { (2006) }\end{array}$ & $\begin{array}{l}\text { Time Series Analysis, } \\
\text { Cointegration (Engle- } \\
\text { Granger) and Causality } \\
\text { (Granger) Analysis }\end{array}$ & $\begin{array}{l}\text { There is a long-term relationship between } \\
\text { growth rate and total tax revenues. } \\
\text { GDP } \leftrightarrow \text { Direct tax } \\
\text { No causality relationship was found between } \\
\text { indirect taxes and growth. }\end{array}$ \\
\hline $\begin{array}{l}\text { Furceri \& Karras } \\
\text { (2008) }\end{array}$ & $\begin{array}{l}\text { Panel Data Analysis } \\
\text { Linear Regression (Fixed } \\
\text { and Random Effects } \\
\text { Estimator) }\end{array}$ & $\begin{array}{l}\text { The increase in tax rates makes a lasting and } \\
\text { negative impact on growth. }\end{array}$ \\
\hline
\end{tabular}


Table 1: Continue

\begin{tabular}{|c|c|c|}
\hline $\begin{array}{l}\text { Kong \& Hoek } \\
(2008)\end{array}$ & $\begin{array}{l}\text { Engle-Granger } \\
\text { Cointegration, Error } \\
\text { Correction Model }\end{array}$ & $\begin{array}{l}\text { The most important reason for an increase in } \\
\text { tax revenues is the increase in GDP. }\end{array}$ \\
\hline Temiz (2008) & \begin{tabular}{|l|} 
Time Series Analysis, \\
Cointegration \\
(Johansen) and Causality \\
(Granger) Analysis
\end{tabular} & $\begin{array}{l}\text { While it is understood that there is a long- } \\
\text { term relationship between growth and indirect } \\
\text { - direct taxes, it was found that there is a } \\
\text { positive relationship with direct taxes, and a } \\
\text { negative relationship with indirect taxes. } \\
\text { GDP } \leftrightarrow \text { Direct tax }\end{array}$ \\
\hline $\begin{array}{l}\text { Padda \& Akram } \\
\text { (2009) }\end{array}$ & $\begin{array}{l}\text { Time Series Analysis, } \\
\text { Linear Regression (OLS } \\
\text { Estimator) }\end{array}$ & $\begin{array}{l}\text { The increase in taxes affects the growth } \\
\text { negatively. }\end{array}$ \\
\hline $\begin{array}{l}\text { Göçer, Mercan, } \\
\text { Bulut, and Dam } \\
\text { (2010) }\end{array}$ & $\begin{array}{l}\text { Time Series Analysis, } \\
\text { ARDL Bounds Test }\end{array}$ & $\begin{array}{l}\text { Total tax revenues and growth are } \\
\text { cointegrated in both short term and long term. }\end{array}$ \\
\hline $\begin{array}{l}\text { Helhel \& Demir } \\
\text { (2012) }\end{array}$ & \begin{tabular}{|l|} 
Time Series Analysis, \\
Cointegration \\
(Johansen) and Causality \\
(Granger) Analysis \\
\end{tabular} & $\begin{array}{l}\text { It was proven that there is an interaction } \\
\text { between tax revenue and growth in the long } \\
\text { term. No interaction was found in the short term. } \\
\text { The effect of indirect tax on growth is weak. }\end{array}$ \\
\hline $\begin{array}{l}\text { Mangır \& Ertuğrul } \\
(2012)\end{array}$ & $\begin{array}{l}\text { Time Series Analysis, } \\
\text { ARDL Bounds Test } \\
\text { Approach }\end{array}$ & $\begin{array}{l}\text { Cointegration was found between tax burden } \\
\text { and growth. } \\
\text { Between tax burden and growth, a statistically } \\
\text { negative relationship was found. }\end{array}$ \\
\hline $\begin{array}{l}\text { Stoilova \& Patanov } \\
(2012)\end{array}$ & $\begin{array}{l}\text { The Regression Analysis } \\
\text { Method }\end{array}$ & $\begin{array}{l}\text { The tax structure based on direct taxes is more } \\
\text { effective in supporting the growth. }\end{array}$ \\
\hline $\begin{array}{l}\text { Fenochietto \& } \\
\text { Pessino (2013) }\end{array}$ & $\begin{array}{l}\text { Data Envelopment } \\
\text { Analysis, Stochastic } \\
\text { Bounds Analysis and } \\
\text { Sensitivity Analysis, } \\
\text { Stochastic Boundary } \\
\text { Model and Mundlack } \\
\text { Random Effects Model }\end{array}$ & $\begin{array}{l}\text { There is a statistically significant and positive } \\
\text { relationship between GDP per capita and tax } \\
\text { revenues at different models and significance } \\
\text { levels. }\end{array}$ \\
\hline $\begin{array}{l}\text { Ahmad, Sial \& } \\
\text { Ahmad (2016) }\end{array}$ & $\begin{array}{l}\text { Time Series Analysis, } \\
\text { ARDL Bounds Test } \\
\text { Approach }\end{array}$ & $\begin{array}{l}\text { It was found that the total tax revenues have } \\
\text { a negative and significant effect on growth in } \\
\text { the long term. They found that indirect taxes } \\
\text { should be reduced and direct taxes should be } \\
\text { increased in order to increase growth. }\end{array}$ \\
\hline $\begin{array}{l}\text { Organ \& Ergen } \\
(2017)\end{array}$ & $\begin{array}{l}\text { Time Series Analysis, } \\
\text { ARDL Approach and } \\
\text { Causality (Granger) } \\
\text { Analysis }\end{array}$ & $\begin{array}{l}\text { It was found that tax burden and growth } \\
\text { are cointegrated, and there is a negative } \\
\text { correlation between the two variables in the } \\
\text { long run. }\end{array}$ \\
\hline $\begin{array}{l}\text { Andrejovská \& } \\
\text { Puliková (2018) }\end{array}$ & $\begin{array}{l}\text { Panel Data Analysis, } \\
\text { Linear Regression } \\
\text { (Random Effects } \\
\text { Estimator for } 5 \text { countries, } \\
\text { Fixed Effects Estimator } \\
\text { for } 23 \text { countries) }\end{array}$ & $\begin{array}{l}\text { In both country groups, GDP and employment } \\
\text { have statistically significant and positive impact } \\
\text { on tax revenues. }\end{array}$ \\
\hline
\end{tabular}


Table 1: Continue

\begin{tabular}{|c|c|c|}
\hline $\begin{array}{l}\text { Karabulut \& Şeker } \\
(2018)\end{array}$ & $\begin{array}{l}\text { Time Series Analysis, } \\
\text { Linear Regression }\end{array}$ & GDP positively affects tax revenues. \\
\hline Karamelikli (2018) & $\begin{array}{l}\text { Time Series, NARDL } \\
\text { Approach }\end{array}$ & $\begin{array}{l}\text { It found an asymmetrical relationship between } \\
\text { growth and tax income. }\end{array}$ \\
\hline $\begin{array}{l}\text { Basheer, Ahmad \& } \\
\text { Hassan (2019) }\end{array}$ & $\begin{array}{l}\text { Panel Data Analysis, } \\
\text { Linear Regression (LSDV, } \\
\text { Fixed and Random } \\
\text { Effects and POLS } \\
\text { Estimator) }\end{array}$ & $\begin{array}{l}\text { It was found that growth has a positive and } \\
\text { significant effect on tax revenues. }\end{array}$ \\
\hline Akıncı (2019) & $\begin{array}{l}\text { Time Series Analysis, } \\
\text { Cointegration (Maki) } \\
\text { Analysis } \\
\end{array}$ & $\begin{array}{l}\text { Cointegration was found between growth and } \\
\text { tax revenues in the long run. }\end{array}$ \\
\hline $\begin{array}{l}\text { Ozturk, Şaşmaz, } \\
\text { Bayar \& Odabaşı } \\
\text { (2019) }\end{array}$ & $\begin{array}{l}\text { Time Series Analysis, } \\
\text { Linear Regression (OLS } \\
\text { Estimator) } \\
\end{array}$ & $\begin{array}{l}\text { It was determined that economic growth } \\
\text { positively affects tax revenues. }\end{array}$ \\
\hline Polat (2019) & $\begin{array}{l}\text { Time Series Analysis, } \\
\text { Cointegration (Maki) } \\
\text { Analysis, Canonical } \\
\text { Regression }\end{array}$ & $\begin{array}{l}\text { A positive relationship was found between } \\
\text { growth and tax revenues in both short term } \\
\text { and long term. }\end{array}$ \\
\hline Boğa (2020) & $\begin{array}{l}\text { Time Series Analysis, } \\
\text { NARDL Approach }\end{array}$ & $\begin{array}{l}\text { It was seen that the total tax revenues increase } \\
\text { economic growth in both short term and long } \\
\text { term and the relationship between the two } \\
\text { variables is asymmetric in both periods. }\end{array}$ \\
\hline $\begin{array}{l}\text { Çiğdem et al. } \\
\text { (2020) }\end{array}$ & $\begin{array}{l}\text { Time Series Analysis, } \\
\text { Cointegration (Engle- } \\
\text { Granger) Analysis }\end{array}$ & $\begin{array}{l}\text { It was determined that an increase in growth } \\
\text { causes a decrease in indirect tax revenues. }\end{array}$ \\
\hline
\end{tabular}

As can be viewed from Table 1, varied methods were used in distinct periods. This study will contribute to the literature since no $\mathrm{HC}$ was found between growth and tax revenues.

\section{Methodology, Data, and Empirical Results}

Analyzed in the present study, annual total tax rates of the period 1985-2018 and GDP data were compiled from the OECD database. Details about the indicators are indicated in Table 2. 
Table 2: Variables

\begin{tabular}{|l|l|c|c|}
\hline Variables & & & Source \\
\hline Tax & Total Tax Revenue (\% GDP) & Rate & OECD \\
\hline GDP & Gross Domestic Product - Spending & Million Dollar & OECD \\
\hline
\end{tabular}

Econometric analyses were conducted using the E-views $10^{+}$software. The regression model examined in the research is as follows:

$$
\begin{gathered}
\mathrm{Tax}=f(\mathrm{GDP}) \\
\ln \operatorname{Tax}_{t}=\alpha_{0}+B_{1} \ln G D P_{t}+\varepsilon_{t}
\end{gathered}
$$

\subsection{Unit Root Test}

This part includes the theories of the customary unit root tests and the unit root tests with structural breaks.

\subsubsection{ADF Unit Root Test}

The Augmented Dickey-Fuller (ADF) unit root test, often preferred in unit root and stationarity analyses in time series, is described as another version of the Dickey-Fuller (DF) test based on the AR(1) process. However, in cases when there is a higher degree of correlation in time series, " $\varepsilon_{\mathrm{t}}$ " (error term series) loses the white noise feature. Therefore, $A R(p)$ process is used, rather than $A R(1)$ process in the ADF test to solve the problem of a high-degree autocorrelation, and " $p$ " lagged difference terms are included in DF equations (Dickey and Fuller, 1979). After this modification process, the ADF equations with intercept, with intercept and trend, and none.

$$
\begin{gathered}
\Delta y_{t}=\delta y_{t-1}+\sum_{i=1}^{p} \beta_{i} \Delta y_{t-i}+\varepsilon_{i} \\
\Delta y_{t}=\mu+\delta y_{t-1}+\sum_{i=1}^{p} \beta_{i} \Delta y_{t-i}+\varepsilon_{i} \\
\Delta y_{t}=\mu+\beta t+\delta y_{t-1}+\sum_{i=1}^{p} \beta_{i} \Delta y_{t-i}+\varepsilon_{i}
\end{gathered}
$$


"In equations (3), (4), and (5) " $\mu$ " is the constant, " $t$ " is the deterministic trend, " $p$ " is the lag length, and " $\varepsilon_{t}$ " is the error term series. Null hypotheses for all three of these ADF equations are the same, indicating that there is a unit root in the series (Gujarati, 2015).

\subsubsection{Phillips Perron Unit Root Test}

DF and ADF unit root tests assume that error terms are independent and homoscedastic (Enders, 2004). However, it has been observed that the many timeseries have error terms that are heterogeneously distributed and weakly dependent.

To solve this problem, Phillips and Perron (1988) developed a new test (nonparametric adjusted), thinking that there might be autocorrelation between error terms. Moreover, Phillips and Perron (1988) found nonparametric modifications in the PP unit root test. The equation, forming the basis for the PP unit root test is shown below:

$$
\Delta y_{t}=a y_{t-1}+x_{t}^{\prime} \delta+\varepsilon_{t}
$$

In equation (6) it refers to " $\alpha=\rho-1$ " whereas " $x_{t}$ " indicates deterministic components (intercept or intercept and trend) while " $\varepsilon_{\mathrm{t}}$ " indicates the error term. Null and alternative hypotheses of the test are as follows: " $H_{0}: \alpha=0$ and $H_{1}: \alpha<0$ ". The null hypothesis indicates that the time series includes a unit root (Çağlayan and Saçaklı, 2006).

\subsection{Hidden Cointegration Relationship}

The HC relationship developed by Granger and Yoon (2002) criticizes the traditional cointegration finding methods based on the logic suggesting that a cointegration relationship occurs when economic variables synchronously react to shocks (Granger and Yoon, 2002). 


$$
\begin{gathered}
x_{t=} x_{t-1}+\varepsilon_{t}=x_{0}+\sum_{i=1}^{t} \varepsilon_{i} \\
y_{t}=y_{t-1}+\epsilon_{t}=y_{0}+\sum_{i=1}^{\iota} \epsilon_{i}
\end{gathered}
$$

In equations (7) and (8) $t=1,2, \ldots$, " $x_{0}$ and $y_{0}$ " indicate initial values whereas " $\varepsilon_{\mathrm{i}}$ and $\epsilon_{i}$ " indicate the white noise series. Both variables in these equations $\left(x_{t}\right.$ and $\left.y_{t}\right)$ demonstrate the original data of the series. The decomposition process to be conducted in the first phase is based on the decomposition of error terms by positive and negative shocks. The decomposition process is as follows: $\varepsilon_{i}^{-}=\min \left(\varepsilon_{i}, d\right)$ and $\varepsilon_{i}^{+}=\max \left(\varepsilon_{i}, d\right) ; \epsilon_{i}^{-}=\min \left(\epsilon_{i}, d\right)$ and $\epsilon_{i}^{+}=\max \left(\epsilon_{i}, d\right)$. The variables that this process is applied to are shown as $\varepsilon_{i}=\varepsilon_{i}^{-}+\varepsilon_{i}^{+}+d$ and $\epsilon_{i}=\epsilon_{i}^{-}+\epsilon_{i}^{+}+d$. Furthermore, $\varepsilon_{i}^{+}, \varepsilon_{i}^{-}, \epsilon_{i}^{+}$, and $\epsilon_{i}^{-}$are assumed to follow the l(1) process (Granger and Yoon, 2002, p. 6). The " $d$ " values in these equations indicate the threshold value and are often assumed to be zero. When these values are replaced in equation (5), $x_{t=} x_{t-1}+\varepsilon_{t}=x_{0}+\sum_{i=1}^{t} \varepsilon_{i}^{-}+\sum_{i=1}^{t} \varepsilon_{i}^{+}$and $y_{t}=y_{t-1}+\epsilon_{t}=y_{0}+\sum_{i=1}^{t} \epsilon_{i}^{-}+\sum_{i=1}^{t} \epsilon_{i}^{+}$ equations are acquired respectively. In the next phase, when it is assumed that $x_{0}$ and $y_{0}$ are constant values, it can be reformulated as $x_{t}=x_{0}+x_{t}^{-}+x_{t}^{+}$and $y_{t=} y_{0}+y_{t}^{-}+y_{t}^{+}$. At this point, the shocks obtained constitute the first phase of the $\mathrm{HC}$ analysis. Moreover, in their studies, Granger and Yoon (2002) studied the cointegration relationship for four different states of two variables such as $X$ and $Y$ (Granger and Yoon, 2002). This relationship was presented by implementing the Engle and Granger (1987) test on positive and negative components.

\subsection{Crouching Error Correction Models}

Granger and Yoon (2002) proposed a crouching error correction model (CECM) based on the results of the $H C$ approach. If there is an $H C$ relationship among the analyzed variables, CECM is as follows:

$$
\begin{aligned}
& \Delta Y_{t}^{+}=\varphi_{0}+\varphi_{1} \varepsilon_{t-1}+\sum_{i=1}^{k} \varphi_{x i} \Delta X_{t-i}^{+}+\sum_{j=1}^{p} \varphi_{y j} \Delta Y_{t-j}^{+}+v_{t} \\
& \Delta X_{t}^{+}=\gamma_{0}+\gamma_{1} \varepsilon_{t-1}+\sum_{i=1}^{k} \gamma_{x i} \Delta X_{t-i}^{+}+\sum_{j=1}^{p} \gamma_{y j} \Delta Y_{t-j}^{+}+v_{t}
\end{aligned}
$$


In the Equations (9) and (10), and indicate error correction terms (ECT). Gonzalo and Granger (1995), defined variables that had insignificant ECT in the error correction equations as the permanent component of the system whereas variables with significant ECT were defined as temporary variables.

Table 3: ADF, PP, ZA and LS Unit Root Tests (Level)

\begin{tabular}{|c|c|c|c|c|c|}
\hline \multirow[b]{2}{*}{ Variables } & \multicolumn{2}{|c|}{ ADF Unit Root Test } & \multicolumn{3}{|c|}{ PP Unit Root Test } \\
\hline & $\begin{array}{l}\text { T-Stat. } \\
\text { (Cons.) }\end{array}$ & $\begin{array}{c}\text { T-Stat. } \\
\text { (Cons. and Trend) }\end{array}$ & Adj. t Stat. (Cons.) & \multicolumn{2}{|c|}{$\begin{array}{c}\text { Adj. t Stat. } \\
\text { (Cons. and Trend) }\end{array}$} \\
\hline Tax & $\begin{array}{c}-2.110525 \\
(0.2420) \\
\end{array}$ & $\begin{array}{c}-1.237971 \\
(0.8856) \\
\end{array}$ & $\begin{array}{c}-2.092883 \\
(0.2486) \\
\end{array}$ & \multicolumn{2}{|c|}{$\begin{array}{c}-1.321345 \\
(0.8648) \\
\end{array}$} \\
\hline GDP & $\begin{array}{c}0.087354 \\
(0.9599) \\
\end{array}$ & $\begin{array}{c}-1.286163 \\
(0.8739) \\
\end{array}$ & $\begin{array}{c}0.055208 \\
(0.9571) \\
\end{array}$ & \multicolumn{2}{|c|}{$\begin{array}{c}-1.397253 \\
(0.8341) \\
\end{array}$} \\
\hline $\operatorname{Tax}^{+}$ & $\begin{array}{c}-2.093293 \\
(0.2485) \\
\end{array}$ & $\begin{array}{c}-1.124963 \\
(0.9088) \\
\end{array}$ & $\begin{array}{c}-2.433325 \\
(0.1410) \\
\end{array}$ & \multicolumn{2}{|c|}{$\begin{array}{c}-0.977117 \\
(0.9333)\end{array}$} \\
\hline Tax & $\begin{array}{c}-0.164104 \\
(0.9334) \\
\end{array}$ & $\begin{array}{c}-1.837102 \\
(0.6629) \\
\end{array}$ & $\begin{array}{c}-0.095273 \\
(0.9417) \\
\end{array}$ & \multicolumn{2}{|c|}{$\begin{array}{c}-1.837102 \\
(0.6629)\end{array}$} \\
\hline $\mathrm{GDP}^{+}$ & $\begin{array}{l}0.148854 \\
(0.9646) \\
\end{array}$ & $\begin{array}{c}-1.527160 \\
(0.7987) \\
\end{array}$ & $\begin{array}{l}0.150854 \\
(0.9648) \\
\end{array}$ & \multicolumn{2}{|c|}{$\begin{array}{c}-1.592102 \\
(0.7737) \\
\end{array}$} \\
\hline \multirow[t]{3}{*}{ GDP- } & $\begin{array}{l}-1.161501 \\
(0.6785) \\
\end{array}$ & $\begin{array}{l}-1.353465 \\
(0.8553) \\
\end{array}$ & $\begin{array}{l}-1.161501 \\
(0.6785) \\
\end{array}$ & \multicolumn{2}{|c|}{$\begin{array}{c}-1.461132 \\
(0.8220) \\
\end{array}$} \\
\hline & \multicolumn{3}{|c|}{ ZA Unit Root Test } & \multicolumn{2}{|c|}{ LS Unit Root Test } \\
\hline & $\begin{array}{l}\text { T-Stat. } \\
\text { (Cons.) }\end{array}$ & $\begin{array}{l}\text { T-Stat. } \\
\text { (Trend) }\end{array}$ & $\begin{array}{c}\text { T-Stat. } \\
\text { (Cons. and Trend) }\end{array}$ & $\begin{array}{l}\text { t Stat. } \\
\text { (Cons.) }\end{array}$ & $\begin{array}{l}\text { t Stat. (Cons. } \\
\text { and Trend) }\end{array}$ \\
\hline Tax & $\begin{array}{c}-2.745 \\
(0.09588) \\
\end{array}$ & $\begin{array}{c}-3.427 \\
(0.00834) \\
\end{array}$ & $\begin{array}{c}-3.820 \\
(0.04644) \\
\end{array}$ & -2.066 & -5.753 \\
\hline GDP & $\begin{array}{c}-1.913 \\
(0.00031)\end{array}$ & $\begin{array}{c}-3.813 \\
(0.00033)\end{array}$ & $\begin{array}{c}-4.609 \\
(0.00035)\end{array}$ & -2.264 & -5.784 \\
\hline
\end{tabular}

Note: ${ }^{*}{ }^{* *},{ }^{* *}$ denote the significance levels of alpha at $.01, .05$, and .10 respectively.

Table 3 indicates the findings of ADF, PP, ZA, and LS tests. The results demonstrate that the series include a unit root.

Table 4: ADF and PP Unit Root Tests (First Difference)

\begin{tabular}{|l|c|c|c|c|}
\hline \multirow{3}{*}{ Variables } & \multicolumn{2}{|c|}{ ADF Unit Root Test } & \multicolumn{2}{c|}{ PP Unit Root Test } \\
\cline { 2 - 5 } & $\begin{array}{c}\text { T-Stat. } \\
\text { (Cons.) }\end{array}$ & $\begin{array}{c}\text { T-Stat. } \\
\text { (Cons. and Trend) }\end{array}$ & $\begin{array}{c}\text { Adj. t Stat. } \\
\text { (Cons.) }\end{array}$ & $\begin{array}{c}\text { Adj. t Stat. } \\
\text { (Cons. and Trend) }\end{array}$ \\
\hline$\Delta$ Tax & -4.973206 & -5.166056 & -4.969272 & -5.147432 \\
& $(0.0003)^{\star}$ & $(0.0011)^{*}$ & $(0.0003)^{\star}$ & $(0.0011)^{*}$ \\
\hline$\Delta$ GDP & -5.018333 & -4.978882 & -5.018325 & -4.978882 \\
& $(0.0003)^{\star}$ & $(0.0018)^{*}$ & $(0.0003)^{\star}$ & $(0.0018)^{*}$ \\
\hline
\end{tabular}




\begin{tabular}{|l|c|c|c|c|}
\hline$\Delta \operatorname{Tax}^{+}$ & $\begin{array}{c}-5.637007 \\
(0.0001)^{*}\end{array}$ & $\begin{array}{c}-6.063683 \\
(0.0001)^{*}\end{array}$ & $\begin{array}{c}-5.636548 \\
(0.0001)^{*}\end{array}$ & $\begin{array}{c}-6.131408 \\
(0.0001)^{*}\end{array}$ \\
\hline$\Delta \operatorname{Tax}^{-}$ & -5.624554 & -5.533307 & -5.624185 & -5.533332 \\
& $(0.0001)^{*}$ & $(0.0005)^{*}$ & $(0.0001)^{*}$ & $(0.0005)^{*}$ \\
\hline$\Delta \mathrm{GDP}^{+}$ & -5.357046 & -5.341829 & -5.358488 & -5.341829 \\
& $(0.0001)^{*}$ & $(0.0007)^{*}$ & $(0.0001)^{*}$ & $(0.0007)^{*}$ \\
\hline$\Delta$ GDP- $^{-}$ & -5.249796 & -5.240197 & -5.249796 & -5.239229 \\
& $(0.0002)^{*}$ & $(0.0010)^{*}$ & $(0.0002)^{*}$ & $(0.0010)^{*}$ \\
\hline
\end{tabular}

Note: ${ }^{*}{ }^{* *},{ }^{* *}$ denote the significance levels of alpha at $.01, .05$, and .10 respectively.

Table 4 shows the ADF and PP test conclusions of the series with their first difference calculated. It was concluded that the integration degree of all the series was "1", and it was observed that the first condition for the $H C$ test was achieved at this phase.

Table 5: Hidden Cointegration

\begin{tabular}{|l|c|c|c|c|}
\hline Engle-Granger (1978) Cointegration Approach \\
\hline Method & \multicolumn{5}{|c|}{ Engle-Granger } \\
\hline Variables & T Stat. & T Prob. & z Stat. & z Prob. \\
\hline Tax & -2.009270 & 0.2373 & -4.068134 & 0.5317 \\
\hline GDP & -2.125379 & 0.1975 & -4.224890 & 0.5157 \\
\hline Granger-Yoon (2002) Hidden Cointegration Approach \\
\hline Method & \multicolumn{5}{|c|}{ Engle-Granger } \\
\hline Variables & T Stat. & T Prob. & z Stat. & z Prob. \\
\hline Tax ${ }^{+}$ & -0.270497 & 0.8988 & -0.515114 & 0.8998 \\
\hline GDP $^{+}$ & -0.000631 & 0.9339 & -0.001216 & 0.9339 \\
\hline Tax $^{+}$ & -1.788559 & 0.3258 & -6.050994 & 0.3505 \\
\hline GDP- $^{-}$ & -1.879333 & 0.2876 & -6.488562 & 0.3175 \\
\hline Tax & -0.868803 & 0.7521 & -2.392472 & 0.7138 \\
\hline GDP $^{-}$ & -1.208930 & 0.6053 & -3.316671 & 0.6109 \\
\hline Tax & $\mathbf{- 2 . 6 9 1 6 0 8}$ & $\mathbf{0 . 0 7 0 0 * * *}$ & $\mathbf{- 1 2 . 5 5 2 6 1}$ & $\mathbf{0 . 0 6 6 0}$ \\
\hline GDP $^{+}$ & $\mathbf{- 2 . 7 0 4 1 0 1}$ & $\mathbf{0 . 0 6 8 2 ^ { * * * }}$ & $\mathbf{- 1 2 . 4 5 1 5 8}$ & $\mathbf{0 . 0 6 8 0 * * *}$ \\
\hline
\end{tabular}

Note: ${ }^{* *},{ }^{* * *}$ denote the significance levels of alpha at $.01, .05$, and .10 respectively.

Table 5 represents the results of both the cointegration (original variables) developed by Engle-Granger (1987) and the cointegration (positive and negative) ingredients of variables developed by Granger and Yoon (2002). The results demonstrated that the original variables did not form a cointegration relationship. In this phase, it was suspected that there was an $H C$ relationship. Thus, four alternatives were found for the $H C$ analysis. However, it was concluded that only 
the tax variable decreased while there was a cointegration relationship in periods when GDP increased. Therefore, the long-run relationship structure between tax - $\mathrm{GDP}^{+}$variables should be estimated within the framework of $H C$ and CECMs.

Table 6: Hidden Cointegration Regression

\begin{tabular}{|l|c|c|c|c|}
\hline Dependent Variable: Tax- & Coefficient & Std. Err. & t Stat. & Prob. \\
\hline Cons. & 0.011610 & 0.017844 & 0.650629 & 0.5202 \\
\hline GDP $^{+}$ & -0.557359 & 0.109032 & -5.111882 & $0.0000^{*}$ \\
Trend & 0.016261 & 0.007961 & 2.042681 & $0.0500^{*}$ \\
\hline Adj. $R^{2}$ & \multicolumn{5}{|l}{} \\
\hline F Stat. / Prob. 362.64 / $0.00000^{*}$
\end{tabular}

Note: ${ }^{*}{ }^{* *},{ }^{* *}$ denote the significance levels of alpha at $.01, .05$, and .10 respectively.

Table 6 shows the estimation of the $H C$ model. A positive shock (a positive development) of $1 \%$ in GDP, in the long run, reduces negativities (decreases) in tax revenues by approximately $0.55 \%$. The following $\mathrm{HC}$ regression is estimated with OLS:

$$
\operatorname{Tax}_{t}^{-}=0.012-0.557 \times G D P_{t}^{+}+0.016 \times \text { Trend }
$$

After this phase, the suggested CECMs will be estimated by Granger and Yoon (2002) for variables between which there is an $H C$ relationship.

Figure 1. Tax ${ }^{+}$- GDP ${ }^{+}$

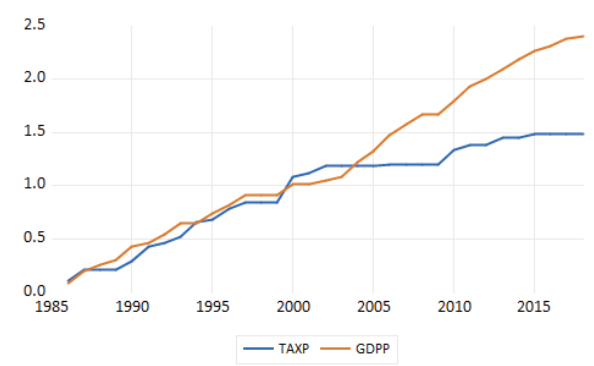

Figure 2. Tax - GDP-

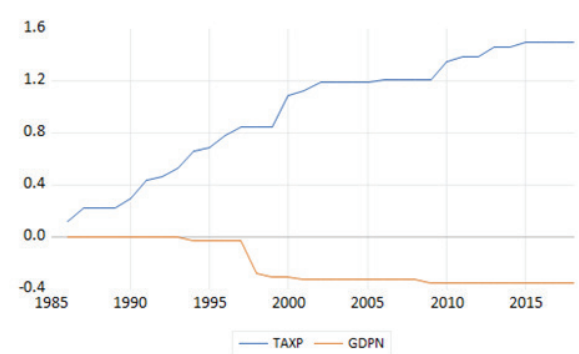


Figure 3. Tax' - GDP+

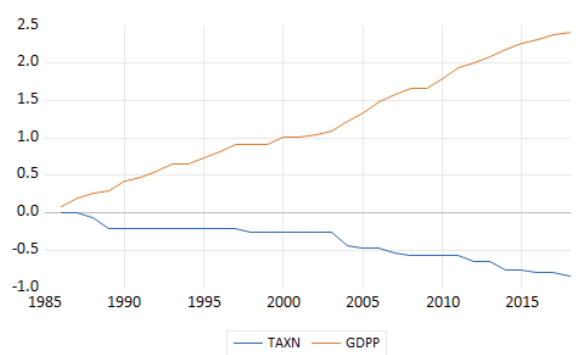

Figure 4. Tax- - GDP-

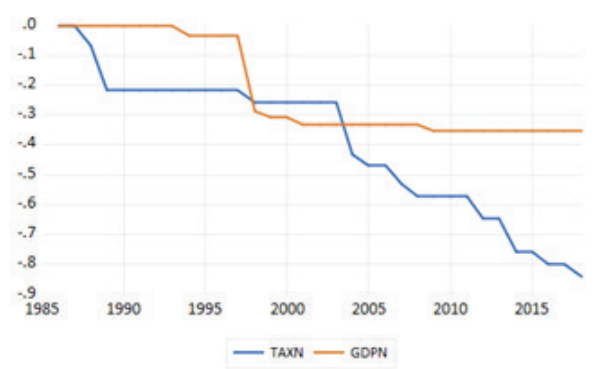

Figure 5. Tax - GDP

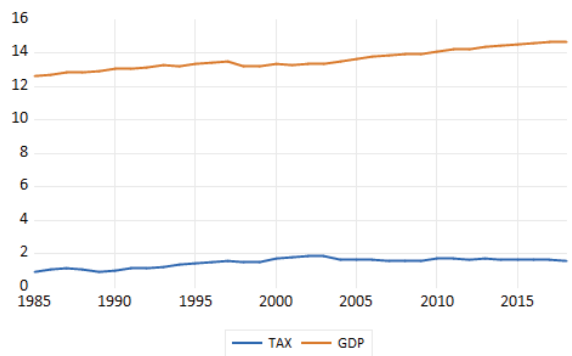

Figures 1, 2, 4, and 5 demonstrate the cases in which evidence could not be found on the cointegration relationship even if the relationship was analyzed in the scope of the present study whereas Figure 3 demonstrates the case in which a cointegration relationship was found. Figure 5 should especially be noted: This figure shows the original data of variables (with both increases and decreases), and both increases and decreases occur in these series. It also indicates only one of the cases in which a cointegration relationship could not be found. After eliminating insignificant terms the CECMs are estimated. 
Table 7: Crouching Error Correction Models

\begin{tabular}{|l|c|c|c|c|}
\hline Model 1 \\
\hline Dependent Variable: Tax & Coefficient & Std. Error & t Stat. & Prob. \\
\hline$\Delta$ GDP $^{+}{ }_{\text {- } 8}$ & -0.362431 & 0.095643 & -3.789436 & $0.0009^{*}$ \\
\hline Model 2 & \multicolumn{1}{|l|}{} \\
\hline Dependent Variable: GDP+ & Coefficient & Std. Error & t Stat. & Prob. \\
\hline Cons. & 0.090955 & 0.029581 & 3.074783 & $0.0077^{\star}$ \\
\hline CCT $_{t-1}$ & -0.822944 & 0.332344 & -2.476182 & $0.0257^{\star \star}$ \\
\hline$\Delta \operatorname{Tax}_{t-7}$ & -0.461488 & 0.211884 & -2.178026 & $0.0458^{\star \star}$ \\
\hline
\end{tabular}

Note: ${ }^{*}{ }^{* *},{ }^{* \star *}$ denote the significance levels of alpha at $.01, .05$, and .10 respectivelyy.

Table 7 demonstrates the CECM proposed by Granger and Yoon (2002). It is observed that the ECT of the first model is not statistically significant; but, the ECT of the second model is statistically significant. These findings indicate that the $\operatorname{Tax}^{-}$is the permanent component whereas the GDP+ is the temporary component. In the long run, the Tax variable is the asymmetrical cause for the $\mathrm{GDP}^{+}$variable. It was therefore concluded that, between taxes and GDP, there was a one-way and long-run asymmetric causality.

\section{Conclusion}

In the study conducted by Çiğdem et al. (2020) in which the tax-GDP relationship was studied, a cointegration relationship was found between variables, and it was noted that an increase in GDP would cause a decrease in indirect taxes. It was concluded in the present study which is a continuation of the previous one that one variable increased as the other one increased and that there was not an asymmetric and synchronous relationship when one variable decreased as well as demonstrating that only tax revenues decreased while there was a cointegration relationship in periods when GDP increased. The hidden cointegration relationship describes a much different cointegration structure, and it is based on the logic suggesting that variables do not always react in the same way to shocks. The results obtained are in parallel with studies by Musanga (2007), Greenidge and Drakes (2009), Karras and Furceri (2009), Romer and Romer (2010), and Dackehag and Hansson (2012) using the traditional approach 
in terms of the direction of this relationship. The present study is an additive to the literature since it is the first study to have applied the hidden cointegration technique on variables analyzed. Moreover, the results obtained are crucial for policy-makers.

\author{
Peer-review: Externally peer-reviewed. \\ Conflict of Interest: The authors have no conflict of interest to declare. \\ Grant Support: The authors declared that this study has received no financial support. \\ Hakem Değerlendirmesi: D1ş bağımsız. \\ Çıkar Çatışması: Yazarlar çıkar çatışması bildirmemiştir. \\ Finansal Destek: Yazarlar bu çalışma için finansal destek almadığını beyan etmiştir.
}

\title{
References/Kaynaklar
}

Ahmad, S., Sial, M. \& Ahmad N. (2016). Taxes and economic growth: an empirical analysis of Pakistan. European Journal of Business and Social Sciences, 5(02), 16-29.

Akıncı, A. (2019). Türkiye'de vergi gelirlerinin ekonomik büyüme üzerindeki etkisi. Finans Ekonomi ve Sosyal Araştırmalar Dergisi, 4(1), 100-106.

Andrejovská, A. \& Puliková, V. (2018). Tax revenues in the context of economic determinants. Montenegrin Journal of Economics, 133. Doi:10.14254/1800-5845/2018.14-1.10

Basheer, M., Ahmad, A. \& Hassan, S. (2019). Impact of economic and financial factors on tax revenue: evidence from the Middle East countries. Accounting, 5(2), 53-60.

Boğa, S. (2020). Türkiye'de vergi gelirleri ve ekonomik büyüme arasındaki asimetrik ilişki: NARDL eşbütünleşme yaklaşımı. Üçüncü Sektör Sosyal Ekonomi Dergisi, 55(1), 487-507. Doi: 10.15659/3. sektor-sosyal-ekonomi.20.03.1311

Chigbu, E.E. \& Njoku, C.O. (2015). Taxation and the Nigerian economy: (1994-2012). Management Studies and Economic Systems, 2(2), 111-128.

Çağlayan, E. \& Saçaklı, İ. (2006). Satın alma gücü paritesinin geçerliliğinin sıfır frekansta spektrum tahmincisine dayanan birim kök testleri ile incelenmesi. Iktisadi ve İdari Bilimler Dergisi, 20(1), 122-137.

Çiğdem, G., Altaylar, M., Köse, T. \& Yılmaz, G.G. (2020). İktisadi krizler ve tüketim eğilimi üzerine ampirik sorgulama: Türkiye'den bir eşbütünleşme örneği. In G. Çiğdem (Ed.), Multidisipliner Yaklaşımla iktisadi Kriz Olgusu Cilt:III (pp.61-103). Ankara, Turkey: Gazi Kitabevi.

Dackehag, M. \& Hansson, Å. (2012). Taxation of income and economic growth: an empirical analysis of 25 Rich OECD countries. Lund University Department of Economics Working Paper No 6.

Dam, M. \& Ertekin, Ş. (2018). Türkiye'de vergi gelirlerinin ekonomik büyüme üzerindeki etkisinin analizi. Vergi Raporu Dergisi, 228, 19-32.

Dickey, D.A. \& Fuller, W.A. (1979). Distribution of the estimators for autoregressive time series with a unit root. Journal of the American Statistical Association, 74(366), 427-431.

Durkaya, M. \& Ceylan, S. (2006). Vergi gelirleri ve ekonomik büyüme. Maliye Dergisi, 150, 79-89. 
Easterly, W. \& Rebelo, S. (1992). Marginal income tax rates and economic growth in developing countries. Policy Research Working Papers, No. 1050. Retrieved from http://documents. worldbank.org/curated/en/432391468766196026/pdf/multi-page.pdf

Easterly, W. \& Rebelo, S. (1993). Marginal income tax rates and economic growth in developing countries. European Economic Review, 37, 409-417.

Easterly, W. \& Rebelo, S. (1993). Fiscal policy and economic growth: an empirical investigation. Journal of Monetary Economics, 32, pp. 417-58.

Enders, W. (2004). Applied Econometric Time Series (2.ed.). United States of America: John Wiley \& Sons.

Engen, S. \& Skinner, J. (1992). Fiscal policy and economic growth. NBER Working Paper, 4223, National Bureau of Economic Research, Cambridge, Mass.

Engle, R. \& Granger, C. (1987). Cointegration and error correction representation: estimation and testing. Econometrica, 55, 251-276.

Fenochietto, M.R. \& Pessino, M.C. (2013). Understanding Countries' Tax Effort. International Monetary Fund, No. 13-244.

Ferretti, M.M.G. \& Roubini, N. (1995). Growth effects of income and consumption taxes: positive and normative analysis. NBER Working Paper Series, Working Paper 5317, 1-40.

Furceri, D. \& Karras, G. (2008). Tax changes and economic growth: empirical evidence for a panel of OECD countries. OECD ECB Public Finance Workshop Frankfurt, 1-29.

Gonzalo, J. \& Granger, C.W. (1995). Estimation of common long-memory components in cointegrated systems. Journal of Business and Economic Statistics, 13, 27-35.

Goode, R. (1980). Limits of Taxation. Finance Development, 17(I), 11-13.

Göçer, I., Mercan, M., Bulut, Ş. \& Dam, M.M. (2010). Ekonomik büyüme ile vergi gelirleri arasındaki ilişki: sınır testi yaklaşımı. Dumlupınar Üniversitesi SBE Dergisi, 28, 97-110.

Granger, C.W. \& Yoon, G. (2002). Hidden cointegration. University of California, Department of Economics Working Paper, San Diego.

Greenidge, K. \& Drakes, L. (2009). Tax policy and macroeconomic activity in Barbados. Retrieved from http://www.centralbank.org.bb Accessed 21 Nov. 2020

Gujarati, D. (2015). Econometrics by example (2. ed.). London, United Kingdom: Macmillan International Higher Education.

Harberger, A.C. (1964). Taxation, resource allocation and welfare, in the role of direct and indirect taxes in the federal reserve system. Princeton University Press for the National Bureau of Economic Research and the Brookings Institution, Princeton, New Jersey. Retrieved from https://www.researchgate.net/ publication/268442018_Taxation_Resource_Allocation_and_Welfare Accessed 15 Dec. 2020

Helhel, Y.\& Demir, Y. (2012) The relationship between tax revenue and economic growth in Turkey: the period of 1975-2011. International Symposium on Sustainable Development, 1(1), 32-40.

Karabulut, R. \& Şeker, K. (2018). Belirlenmiş değişkenlerin vergi gelirleri üzerindeki etkisi: çoklu doğrusal regresyon analizi. Süleymen Demirel Üniversitesi IIBF Dergisi, 23(3), 1049-1070.

Karamelikli, H. (2018). Dolaylı ve dolaysız vergilerin ekonomik aktiviteler üzerindeki simetrik ve asimetrik etkileri. Maliye ve Finans Yazıları, 110, 95-110. 
Karras, G. \& Furceri, D. (2009). Taxes \& growth in Europe. South-Eastern Europe Journal of Economics, 2, 181-204.

King, R.G. \& Rebelo, S. (1990). Public policy and economic growth: developing neoclassical implications. Journal of Political Economy, 98(5), 126-150.

Knight, F.H. (1944). Diminishing returns from investment. J Polit Econ, 52(3), $26-47$.

Koch, S.F., Schoeman, N.J. \& Van Tonder, J.J. (2005). Economic growth and the structure of taxes in South Africa: 1960-2002. South African Journal of Economics, 73(2), 190-210.

Koester, R.B. \& Kormendi, R.C. (1989). Taxation, aggregate activity and economic growth: crosscountry evidence on some supply side hypotheses. Economic Inquiry, 27, 367-387. Retrieved from https://deepblue.lib.umich.edu/bitstream/handle/2027.42/35806/b1410787.0001.001. pdf? sequence=2\&isAllowed=y

Kong, S. \& Hoek, M.P. (2008). Is the growth of Chinese annual tax revenues unnatural?. Journal of Public Budgeting Accounting \& Financial Management, 20(4), 554-570.

Lucas, R.E. (1988). On the mechanics of economic development. Journal of Monetary Economics, 22, 3-42.

Malthus, T. R. (1798). An essay on the principle of population. History of Economic Thought Books, McMaster University Archive for the History of Economic Thought, number malthus 1798.

Mangır, F. \& Ertuğrul, H.M. (2012). Vergi yükü ve ekonomik büyüme ilişkisi: 1988-2011 Türkiye örneği. Maliye Dergisi, 162, 256-265.

Mankiw, G., Weinzierl, M. \& Yagan, D. (2009). Optimal taxation in theory and practice. Journal of Economic Perspectives, 23(4), 147-174. DOI:10.3386/w15071

Marsden, K. (1983). Links between taxes and economic growth. World Bank Staff Working Papers, No. 605

Mendoza, E., Milesi-Ferretti, G.M. \& Asea, P. (1997). On the effectiveness of tax policy in altering longrun growth: Harberger's superneutrality conjecture. Journal of Public Economics, 66, 99-126.

Musanga, B. (2007). Effects of taxation on economic growth (Uganda's experience: 1987-2005). Unpublished Misc Qualitative Economics. University of Makerere.

Mutaşcu, M.I. \& Dănuleţiu, D.C. (2011). Taxes and economic growth in Romania. A VAR approach. Annales Universitatis Apulensis Series Oeconomica, 13(1), 94-105.

Myles, G. (2000). Taxation and economic growth. Fiscal Studies, 21(1), 141-168. DOI:10.1111/j.1475-5890.2000.tb00583.x

Organ, I. \& Ergen, E. (2017). Türkiye'de vergi yükünün ekonomik büyümeye etkileri üzerine bir çalışma. Pamukkale Üniversitesi Sosyal Bilimler Enstitüsü Dergisi, 27, 197-207. DOI: 10.5505/ pausbed.2017.75508

Öztürk, Ö.F., Şaşmaz, M.Ü., Bayar, Y. \& Odabaşı, H. (2019). Türkiye'de başlıca ekonomik değişkenlerin vergi gelirleri üzerindeki etkisi: çoklu doğrusal regresyon analizi. Journal of Turkish Court of Accounts / Sayistay Dergisi, 115, 37-53.

Padda, I.U.H. \& Akram, N. (2009). The impact of tax policies on economic growth: evidence from South-Asian economies. The Pakistan Development Review, 48(4), 961-971.

Parasız, İ. (2008). Büyüme Teorileri (3.bs.). Bursa: Ezgi Kitabevi.

Phillips, P.C.B. \& Perron, P. (1988). Testing for a unit root in time series regression. Biometrika, 75(2), 335-346. 
Piana, V. (2003). Tax Revenue, Economics Web Institute. Retrieved from http://www. economicswebinstitute.org/glossary/taxrev.htm\#determinants

Polat, M.A. (2019). Ekonomik büyüme ile vergi gelirleri arasındaki ilişkinin incelenmesi: Türkiye örneği. Insan ve Toplum Bilimleri Araştırmaları Dergisi, 8(3), 1991-2009.

Ramsey, F.P. (1928) A mathematical theory of saving. Economic Journal, 38, 543-559. http://dx.doi. org/10.2307/2224098

Ricardo, D. (1817). On the principles of political economy and taxation (John Murray, London). In: Sraffa, P., Ed., The Works and Correspondence of David Ricardo, Vol. 1, Cambridge University Press, Cambridge, 1951.

Romer, P.M. (1986). Increasing returns and long run growth. The Journal of Political Economy, 94(5), 1002-1037.

Romer, P.M. (1990). Endogenous technological change. The Journal of Political Economy, 98(5), 71-102.

Romer, C.D. \& Romer, D.H. (2010). The macroeconomic effects of tax changes: estimates based on a new measure of fiscal shocks. American Economic Review American Economic Association, 100(3), 763-801.

Schumpeter, J.A. (1934). The theory of economic development: an inquiry into profits, capital, credits, interest, and the business cycle. Transaction Publishers, Piscataway.

Solow, R.M. (1956). A contribution to the theory of economic growth. Quarterly Journal of Economics, 70(1), 65-94.

Smith, A. (1776 [1937]). An inquiry into the nature and causes of the wealth of nations. Edited by Cannan. New York: Modern Library.

Stoilova, D. \& Patanov, N. (2012). An empirical evidence for the impact of taxation on economy growth in the European Union. Retrieved from https://dialnet.unirioja.es/descarga/ articulo/4788887.pdf

Swan, T.W. (1956). Economic growth and capital accumulation. The Economic Record, 32(2), 334-361.

Takumah, W. (2014). Cointegration and causality between tax revenue and economic growth in Ghana. International Research Journal of Marketing and Economics, 1(6), 30-44.

Tanzi, V. (1987). Quantitative characteristics of the tax systems of developing countries. In D. Newbery \& N. Stern (Eds.), The Theory of Taxation for Developing Countries (pp 205-241). New York: Oxford University Press.

Tanzi, V., and Lee, H.H. (1996). Fiscal policy and long-run growth. IMF Working Papers, 1996(119). Doi. https://doi.org/10.5089/9781451854121.001

Temiz, D. (2008). Türkiye'de vergi gelirleri ve ekonomik büyüme ilişkisi: 1960-2006 dönemi. 2. Ulusal İktisat Kongresi, 20-22 Şubat, İzmir. Erişim Adresi https://debis.deu.edu.tr/userweb/iibf_kongre/ dosyalar/temiz.pdf. Accessed 21 Oct 2020

Widmalm, F. (2001). Tax Structure and Growth: Are Some Taxes Better Than Others. Public Choice, 107, 199-219.

Young, A. (1928). Increasing return and economic progress. Economic Journal, Vol.38.

Yeldan, E. (2010). Iktisadi Büyüme ve Bölüşüm Teorileri. Ankara: Efil Yayınevi. 